\title{
KEWENANGAN KELEMBAGAAN NEGARA SETELAH PERUBAHAN UUD 1945
}

\author{
Jundiani \\ Fakultas Syariah UIN Maulana Malik Ibrabim Malang \\ Mobile Phone:081803814060 \\ E-mail:jundis3@yahoo.com
}

\begin{abstract}
Abstrak
Tujuan penelitian ini adalah menggambarkan secara sistematis hal-hal yang berkaitan dengan keewenangan kelembagaan negara setelah perubahan UUD 1945. Metode penelitiannya adalah penelitian bukum-normatif dengan menggunakan pendekatan konsep dan perundang-undangan. Hasil dari penelitian ini menyimpulkan bahwa adanya perubahan mendasar terkait dengan pola pembagian kekuasaan pada tiga cabang kekuasaan ; legislatif, eksekutif, dan yudikatif. Lembaga berwenang dalam pembuatan UU, lembaga eksekutif tetap dalam tugas pemerintahan dan lembaga yudisial telah memperkuat fungsi dan peranannya di bidang peradilan dengan membentuk institusi baru yaitu Mabkamah Konstitusi. Lembaga ini mempunyai kewvenangan melakukan uji materi (judicial review) UU atas UUD, yang sebelumnya menjadi tugas dari $M A$.

The objective of this research is to systematically describe aspects relating to the authority of state instrumentalities after the amandment of UUD 1945. The method of this research is normativelegal research using conceptual legislation approaches. The result reveals a fundamental changing on authority distribution pattern within three authority branches: legislative, executive and judicative. The legislative body of the state holds an authority to dispense regulations, while the executive body is responsible for running the governance, and the judicial body strengthens its function and its role in court system and possesses authority to form new institution namely Constitutional Court. This institution bas the authority to undertake judicial review on the Constitution which is used to be the responsibility of Supreme Court.
\end{abstract}

Kata Kunci: Kewenangan Kelembagaan Negara, Perubahan UUD 1945

\section{Pendahuluan}

UUD 1945 sebagai sebuah konstitusi negara Indonesia ditetapkan oleh para pendiri negara pada tanggal 18 Agustus 1945 bersifat sementara dan dibuat dalam keadaan tergesagesa. Sebagai hukum dasar, Undang-Undang Dasar 1945 bukan hanya merupakan dokumen hukum, tetapi juga mengandung aspek lain seperti; pandangan hidup, cita-cita, dan falsafah yang merupakan nilai luhur bangsa dan menjadi landasan dalam penyelenggaraan negara. Di dalam UUD 1945 juga terkandung konsep bahwa negara Indonesia menganut paham konstitusionalisme, konsep negara hukum, dan prinsip demokrasi.

Perubahan UUD 1945 yang dilakukan oleh Majelis Permusyawaratan Rakyat (MPR), selain merupakan perwujudan tuntutan reformasi, juga sejalan dengan pidato Ir. Soekarno, Ketua Panitia Penyusun UUD 1945 
dalam Rapat PPKI tanggal 18 Agustus 1945. Pada kesempatan itu ia menyatakan antara lain bahwa, UUD 1945 adalah bersifat sementara dan kilat, serta merupakan revolutiegrondwet. Dari pernyataan itu tersirat adanya pesan kepada bangsa Indonesia untuk melakukan penyempurnaannya di kemudian hari.

Selain itu, perubahan UUD 1945 memenuhi sila keempat Pancasila, yang penerapannya berlangsung di dalam sistem perwakilan atau permusyawaratan. Orang-orang yang duduk dalam lembaga tersebut merupakan hasil pemilihan umum. Hal itu selaras dengan perubahan UUD 1945 mengenai pemilihan presiden dan wakil presiden serta anggota lembaga perwakilan yang dipilih oleh rakyat.

Dengan perubahan UUD 1945, masyarakat Indonesia meneguhkan diri sebagai negara yang menganut demokrasi konstitusional dengan meletakkan kedaulatan tetap berada di tangan rakyat dan dilaksanakan menurut UUD 1945, pengaturan presiden/wakil presiden dan wakil-wakil rakyat yang dipilih melalui pemilu, penegasan sebagai negara hukum, dan adanya kekuasaan kehakiman yang merdeka. Perubahan tersebut juga mempertegas pembagian kekuasaan antar lembaga negara dengan sistem saling mengawasi dan saling mengimbangi (checks and balances), mempertegas sistem pemerintahan presidensial dengan meniadakan istilah kepala negara dan kepala pemerintahan, dan tetap mempertahankan NKRI.

SebelumperubahanUUD1945, kedudukan UUD 1945 sebagai sumber hukum tertinggi memiliki sifat yang supel (elastis), karena hanya memuat hal-hal pokok yang pengaturan lebih rinci diserahkan kepada undang-undang dengan mengedepankan semangat para penyelenggara negara dan para pemimpin pemerintahan yang baik dalam praktiknya.

Sifat UUD 1945 yang supel tersebut dalam praktiknya telah menimbulkan berbagai penafsiran terhadap rumusan pasal-pasal yang dikandungnya. Pengutamaan semangat para penyelenggara negara dan para pemimpin pemerintahan ternyata belum cukup, karena tidak didukung dengan ketentuan konstitusi yang memuat aturan dasar tentang kehidupan yang demokratis, supremasi hukum, pemberdayaan rakyat, penghormatan HAM, dan otonomi daerah. Hal ini membuka peluang bagi berkembangnya praktik penyelenggaraan negara yang tidak sesuai dengan Pembukaan UUD 1945.

Dasar pemikiran yang melatarbelakangi dilakukannya perubahan UUD 1945, antara lain sebagai berikut:

1. Terbentuknya struktur ketatanegaraan yang bertumpu pada kekuasaan tertinggi di tangan MPR yang sepenuhnya melaksanakan kedaulatan rakyat. Hal itu berakibat pada tidak terjadinya saling mengawasi dan saling mengimbangi (checks and balances) pada institusi-institusi ketatanegaraan.

2. UUD 1945 memberikan kekuasaan yang sangat besar kepada pejabat eksekutif (Presiden). Sistem yang dianut oleh UUD 1945 adalah dominan eksekutif (executive heavy, executive power), yakni kekuasaan dominan berada di tangan Presiden.

3. UUD Dasar 1945 memberikan kewenangan kepada kekuasaan Presiden untuk mengatur hal-hal penting dengan undang-undang.

4. Rumusan UUD 1945 tentang semangat penyelenggara negara belum cukup didukung ketentuan konstitusi yang memuat aturan dasar tentang kehidupan yang demokratis, supremasi hukum, pemberdayaan rakyat, penghormatan hak asasi manusia, dan otonomi daerah.

Dengan demikian tujuan perubahan UUD 1945 adalah untuk menyempurnakan aturan dasar mengenai jaminan dan pelaksanaan kedaulatan rakyat serta memperluas partisipasi rakyat agar sesuai dengan perkembangan paham demokrasi; dan menyempurnakan aturan dasar penyelenggaraan negara secara demokratis dan modern, antara lain melalui pembagian kekuasaan yang lebih tegas, saling mengawasi dan saling mengimbangi (checks and balances) yang lebih ketat dan transparan, dan 
pembentukan lembaga-lembaga negara yang baru untuk mengakomodasi perkembangan kebutuhan bangsa dan tantangan zaman.

Sehubungan dengan latar belakang masalah diatas, maka fokus kajian penelitian ini adalah kewenangan kelembagaan negara setelah perubahan UUD 1945. Tujuan penelitian ini adalah menggambarkan secara sistematis hal-hal berkaitan dengan kewenangan kelembagaan negara setelah perubahan UUD 1945. Penelitian ini dari segi hukum bersifat eksploratif dan dikaji dari segi teori hukum ketatanegaraan.

\section{Teori Perubahan Undang-Undang Dasar}

Moh. Mahfud ${ }^{1}$ dalam bukunya "Amandemen Konstitusi Menuju Reformasi Tata Negara", mempertanyakan mengapa UUD 1945 selalu melahirkan pemerintahan yang otoriter dan korup. Pada bagian lain, ia juga menyangsikan bahwa negara Indonesia yang berdasar konstitusi tertulis, UUD 1945, tidak pernah melahirkan pemerintahan yang demokratis atau tidak pernah melahirkan pemerintahan yang konstitusional. Beberapa alasannya dikemukakan yaitu karena UUD 1945 tidak memuat secara ketat materi-materi yang secara substansial harus ada pada setiap konstitusi, yakni perlindungan hak asasi manusia dan pembatasan kekuasaan bagi penyelenggara negara. Secara lebih rinci jika kajian atas isi UUD 1945 didekati dengan studi socio legal tentang sejarah konstitusionalisme, HAM, dan demokrasi tampak bahwa UUD 1945 memang tidak memenuhi syarat sebagai aturan main politik yang (seharusnya) mewadahi konstitusionalisme.

Dalam konteks pertanyaan di atas, Adnan Buyung Nasution ${ }^{2}$ berpendirian bahwa pemerintahan yang konstitusional itu bukan pemerintahan sekedar sesuai dengan bunyi pasal-pasal konstitusi, melainkan

${ }^{1}$ Moh. Mahfud, Amandemen Konstitusi Menuju Reformasi Tatanegara. (Yogyakarta: UII Press, 1999), h. 54 dan 62.

${ }^{2}$ Adnan Buyung Nasution, Aspirasi Pemerintahan Konstitusional di Indonesia (Terjemahan oleh Sylvia Tiwon, Jakarta: Grafiti Press, 1995), h. 119. pemerintahan yang sesuai dengan bunyi konstitusi yang memang menurut esensiesensi konstitusionalisme.

Ketidakberhasilan UUD 1945 sebagai penjaga dari pelaksanaan prinsip-prinsip konstitusionalisme dan demokratis di atas, hambatan terbesarnya ada pada sifat UUD 1945, yang lebih berorientasi kepada penguatan negara (state oriented), sehingga rakyat berada dalam posisi subordinat atau bahkan termarjinalkan.

Menurut Bagir Manan", "pembaruan" UUD adalah memperbarui UUD dengan cara menambah, merinci, dan menyusun ketentuan yang lebih tegas. Kata "pembaruan" di sini termasuk pula memperkukuh sendi-sendi yang telah menjadi konsensus nasional seperti dasar negara, bentuk negara kesatuan, dan bentuk pemerintahan republik.

\section{Konsep Konstitusi dan Konstitusionalisme}

Berlakunya suatu konstitusi sebagai hukum dasar yang mengikat didasarkan atas kekuasaan tertinggi atau prinsip kedaulatan yang dianut dalam suatu negara. Jika negara menganut paham kedaulatan rakyat, maka sumber legitimasi konstitusi adalah rakyat. Hal ini yang disebut oleh para ahli sebagai constituent power ${ }^{4}$ yang merupakan kewenangan yang berada di luar dan sekaligus di atas sistem yang diaturnya. Karena itu, di lingkungan negara-negara demokrasi, rakyatlah yang dianggap menentukan berlakunya suatu konstitusi.

Dengan dikembangkannya pengertian constituent power berkaitan pula dengan pengertian hirarki hukum (bierarchy of law). Konstitusi merupakan hukum yang lebih tinggi atau bahkan paling tinggi serta paling fundamental sifatnya, karena konstitusi itu sendiri merupakan sumber legitimasi atau landasan otorisasi bentuk-bentuk hukum atau peraturan perundang-undangan yang

\footnotetext{
3 Bagir Manan, Pembaruan UUD 1945(Jurnal Magister Hukum: Vol. 2 No.1, Pebruari 2000), h. 12.

4 Lihat juga Brian Thomson, Textbook on Constitutional and Administrative Law, edisi ke-3 (London: Blackstone Press Ltd., 1997), h. 5.
} 
lain. Sesuai dengan prinsip hukum yang berlaku universal, maka agar peraturan yang tingkatannya berada di bawah UUD dapat berlaku dan diberlakukan, peraturan-peraturan itu tidak boleh bertentangan dengan hukum yang lebih tinggi tersebut.

Dasar yang paling tepat dan kokoh bagi sebuah negara demokrasi adalah sebuah negara konstitusional (constitusional state) yang bersandar pada sebuah konstitusi yang kokoh pula. Konstitusi yang kokoh hanyalah yang jelas paham konstitusinya atau konstitusionalismenya, yaitu yang mengatur secara rinci batas-batas kewenangan dan kekuasaan lembaga legislatif, eksekutif dan yudisial secara seimbang dan saling mengawasi (checks and balances), serta memberikan jaminan yang cukup luas dalam arti penghormatan (to respect), perlindungan (to protect), dan pemenuhan (to fulfill) hak warga negara dan hak asasi manusia. Dengan kata lain, konstitusionalisme adalah paham mengenai pembatasan kekuasaan dan jaminan hak-hak rakyat melalui konstitusi. ${ }^{5}$

Konsensus yang menjamin tegaknya konstitusionalisme di jaman moderen pada umumnya dipahami bersandarkan pada tiga elemen kesepakatan (concensus), yaitu: ${ }^{6}$

a. Kesepakatan tentang tujuan atau cita-cita bersama (the general goals of society or general acceptance of the some philosophy of agreement).

b. Kesepakatan tentang the rule of law sebagai landasan pemerintahan atau penyelenggaraan negara (the basis of government).

c. Kesepakatan tentang bentuk institusiinstitusi dan prosedur-prosedur ketatanegaraan (the form of constitutions and procedures).

Kesepakatan (concensus) yang pertama, yaitu berkenaan dengan cita-cita bersama yang

5 A. Mukthie Fadjar, Hukum Konstitusi \& Mabkamah Konstitusi (Jakarta: Konstitusi Press, 2006, h. 34-35.

${ }^{6}$ Jimly Asshiddiqie, Konstitusi \& Konstitusionalisme Indonesia (Jakarta: Sekretariat Jenderal dan Kepaniteraan Mahkamah Konstiytusi RI, 2006), h. 25-27. sangat menentukan tegaknya konstitusi dan konstitusionalisme di suatu negara. Karena cita-cita bersama itulah yang pada puncak abstraksinya paling mungkin mencerminkan kesamaan-kesamaan kepentingan diantara sesama warga masyarakat yang dalam kenyataannya harus hidup di tengah pluralisme atau kemajemukan.

Kesepakatan kedua adalah kesepakatan bahwa basis pemerintahan didasarkan atas aturan hukum dan konstitusi. Kesepakatan kedua ini juga sangat prinsipil, karena dalam setiap negara harus ada keyakinan bersama bahwa apapun yang hendak dilakukan dalam konteks penyelenggaraan negara haruslah didasarkan atas rule of the game yang ditentukan bersama. Istilah yang biasa digunakan untuk itu adalah rule of law yang dipelopori oleh A.V. Dicey. Istilah rule of law jelas berbeda dengan istilah rule by the law. Dalam istilah yang kedua ini kedudukan hukum (law) digambarkan hanya sekedar bersifat instrumentalis atau alat, sedangkan kepemimpinan tetap berada di tangan orang atau manusia, yaitu "the rule of man by law".

Kesepakatan ketiga adalah berkenaan dengan: (a) bangunan organ negara dan prosedur-prosedur yang mengatur kekuasaannya, (b) hubungan-hubungan antar organ negara itu sama lain, serta (c) hubungan antaraorgan-organnegaradenganwarganegara. Dengan adanya kesepakatan itu, maka isi konstitusi dapat dengan mudah dirumuskan karena benar-benar mencerminkan keinginan bersama berkenaan dengan institusi kenegaraan dan mekanisme ketatanegaraan yang hendak dikembangkan dalam kerangka kehidupan negara berkonstitusi (constitutional state). Kesepakatan-kesepakatan itulah yang dirumuskan dalam dokumen konstitusi yang diharapkan jadi pegangan bersama untuk kurun waktu yang cukup lama.

\section{Konsep Negara Hukum}

Dalam Ensiklopedia Indonesia, istilah "negara hukum" (rechtstaat) yang dilawankan dengan negara kekuasaan, (machtstaat) dirumuskan 
sebagai berikut:

Negara hukum (bahasa Belanda: rechtstaat): negara bertujuan untuk untuk menyelenggarakan ketertiban hukum, yakni tata tertib yang umumnya berdasarkan hukum yang terdapat pada rakyat. Negara hukum menjaga ketertiban hukum supaya jangan sampai terganggu dan agar semuanya berjalan menurut hukum. ${ }^{7}$

Negara kekuasaan (bahasa Belanda: machtstaat): negara yang bertujuan untuk memelihara dan mempertahankan kekuasaan semata-mata. Gumplowics, antara lain mengajarkan bahwa negara itu tidak lain adalah "Eine Organisation der herrschaft einer Minoritar uber eine Majotaritat' (Organisasi dan kekuasaan golongan kecil atas golongan besar). Menurut pendapatnya, hukum berdasarkan ketaatan golongan yang lemah kepada golongan kuat. ${ }^{8}$

Untuk mengkualifikasi apakah suatu negara termasuk tipe negara hukum atau bukan, perlu diselidiki apakah di dalam konstitusi/ UUD negara tersebut tercantum penegasan, baik secara eksplisit maupun implisit, bahwa negara tersebut menyatakan dirinya sebagai suatu negara hukum atau bukan. Di samping itu, perlu diselidiki juga apakah di dalam konstitusi/UUD tersebut atau peraturan perundang-undangan lainnya termuat ketentuan mengenai ciri-ciri atau unsur-unsur yang penting bagi sebuah tipe negara hukum.

Kalau dicermati, UUD 1945 berbeda dengan dua konstitusi lainnya yang pernah berlaku di Indonesia, yaitu konstitusi RIS dan UUDS 1950, yang baik dalam Mukadimah maupun Batang Tubuhnya, menegaskan secara ekplisit bahwa negara Indonesia merupakan sebuah negara hukum yang demokratis. Sedangkan dalam UUD 1945 penegasan tersebut tidak ada, akan tetapi setelah dilakukan perubahan pada tahap ketiga menjadikan Pasal 1 berbunyi:

1. Negara Indonesia ialah Negara Kesatuan, yang berbentuk Republik;

${ }^{7}$ Negara Hukum, Ensiklopedia Indonesia (N-Z), (N.V.W Van Hoeve), h. 983.

${ }^{8}$ Ibid., h. 984.
2. Kedaulatan berada di tangan rakyat dan dilaksanakan menurut Undang-Undang Dasar;

3. Negara Indonesia adalah negara hukum.

Meskipun demikian, sejak Orde Baru bangsa Indonesia telah menyepakati negara Indonesia yang berdasarkan Pancasila dan UUD 1945 adalah sebuah tipe negara hukum meskipun dengan ciri khasnya yang bercorak keindonesiaan.

Sejak berdirinya negara Indonesia, para pendiri bangsa (the founding fathers) telah mengkonsepsikan bahwa negara Indonesia merupakan negara yang berdasarkan hukum, negara yang demokratis (berkedaulatan rakyat), berdasarkan Ketuhanan YME, dan berkeadilan sosial. Dengan demikian, dapat dikatakan bahwa negara Indonesia merupakan theo-demokratische-sozial-rechtstaat. ${ }^{9}$

Perumusan yang dipakai oleh pembentuk UUD 1945, yaitu "Indonesia adalah negara yang berdasarkan atas hukum" dengan rumusan "rechtstaat" diantara dua tanda kutip, menurut Padmo Wahyono, ${ }^{10}$ menunjukkan bahwa pola yang diambil tidak menyimpang dari konsep negara hukum pada umumnya (genusbegrip), namun disesuaikan dengan kondisi Indonesia atau digunakan dengan ukuran pandangan hidup ataupun pandangan bernegara kita.

Dengan demikian, dapat dikatakan bahwa konsep negara hukum Indonesia menurut UUD 1945 ialah negara hukum Pancasila, yaitu konsep negara hukum dimana satu pihak harus memenuhi kriteria dari konsep negara hukum pada umumnya (yaitu ditopang oleh tiga pilar: pengakuan dan perlindungan hak asasi manusia, peradilan yang bebas dan tidak memihak, dan asas legalitas dalam arti formal maupun material). Sedangkan di lain pihak diwarnai oleh aspirasi-aspirasi keindonesiaan yaitu lima nilai fundamental dari Pancasila. ${ }^{11}$

9 A. Mukthie Fadjar, Konsep Negara Hukum dan Pembangunan, (Thesis, 1985).

${ }^{10}$ Padmo Wahyono, Indonesia Negara Berdasar Atas Hukum (Jakarta: Ghalia Indonesia, 1983), h. 7.

11 A. Mukthi Fadjar, Tipe Negara Hukum, (Malang: Bayumedia Publishing, 2005), h. 86. 
Konsep negara hukum berdasarkan Pancasila dan UUD 1945 dapat dirumuskan baik secara material maupun yuridis formal. Rumusan secara material negara hukum Pancasila didasarkan pada cara pandang (paradigma) bangsa Indonesia dalam bernegara yang bersifat integralistik khas Indonesia, yaitu asas kekeluargaan yang maknanya ialah bahwa yang diutamakan adalah rakyat banyak, namun harkat dan martabat manusia tetap dihargai, dan paradigma kita tentang hukum yang berfungsi pengayoman yaitu menegakkan demokrasi termasuk mendemokratisasikan hukum, berkeadilan sosial, dan berperikemanusiaan. ${ }^{12}$

Atas dasar paradigma bangsa Indonesia tentang negara dan hukum itu, rumusan secara materiil negara hukum Pancasila menurut Padmo Wahyono ${ }^{13}$ adalah sebagai berikut: suatu kehidupan berkelompok bangsa Indonesia, atas berkat rahmat Allah Yang Mahakuasa dan didorong oleh keinginan yang luhur supaya berkehidupan kebangsaan yang bebas dalam arti merdeka, berdaulat, bersatu, adil, dan makmur, yang didasarkan hukum baik yang tertulis maupun yang tidak tertulis sebagai wahana untuk ketertiban dan kesejahteraan dengan fungsi pengayoman dalam arti menegakkan demokrasi, perikemanusiaan, dan keadilan sosial.

Sedangkan secara yuridis formal, dengan memperhatikan ketentuan dalam pasal-pasal UUD 1945 dan dengan membandingkannya dengan konsep negara hukum liberal (yang menurut F. Julius Stahl mengandung empat unsur yaitu: pengakuan dan perlindungan hak asasi manusia, pembagian kekuasaan negara, pemerintahan berdasarkan undang-undang, dan peradilan administrasi) dan konsep rule of law (yang menurut A.V. Dicey mengandung tiga unsur yaitu: supremation of law, equality before the law, dan the constitution based on the individual rights), negara hukum Pancasila mengandung lima unsur sebagai berikut: ${ }^{14}$

\footnotetext{
12 Padmo Wahyono, Pembangunan Hukum di Indonesia, (Jakarta: Indo-Hill Co., 1989), h. 153-155.

13 Ibid., h.156.

14 Ibid., h.156-158.
}

1. Pancasila merupakan sumber dari segala sumber hukum, yang berarti kita menghendaki satu sistem hukum nasional yang dibangun atas dasar wawasan kebangsaan, wawasan nusantara, dan wawasan Bhineka Tunggal Ika;

2. MPR adalah lembaga negara, yang berwenang mengubah dan menetapkan UUD yang melandasi segala peraturan perundang-undangan lainnya, di mana undang-undang dibentuk oleh DPR bersama-sama Presiden. Hal ini menunjukkan prinsip legislatif yang khas Indonesia, kekeluargaan, atau kebersamaan;

3. Pemerintahan berdasarkan sistem konstitusi, yaitu suatu sistem yang tertentu yang pasti dan yang jelas dimana hukum yang hendak ditegakkan oleh negara dan yang membatasi kekuasaan penguasa/ pemerintahan agar pelaksanaannya teratur dan tidak simpang siur harus merupakan satu tertib dan satu kesatuan tujuan. Konstitusi merupakan suatu hukum dasar dalam bernegara dimana semua peraturan hukum (baik yang tertulis maupun yang tidak tertulis) dapatdikembalikan. Rumusan itu berbeda dengan rumusan rechtstaat atau rule of law yang lebih menekankan rumusan negara berdasarkan atas hukum atau negara yang bermanfaat jadi lebih luas.

4. Segala warga negara bersamaan kedudukannya dalam hukum dan pemerintahan dan wajib menjunjung hukum dan pemerintahan itu dengan tiada kecualinya [pasal 27 ayat (1) UUD 1945]. Prinsip itu lebih jelas dan lengkap daripada prinsip equalitiy before the law dalam konsep rule of law, karena selain menyangkut persamaan dalam hak-hak politik, juga menekankan persamaan dalam kewajiban.

5. Kekuasaan kehakiman adalah kekuasaan yang merdeka, artinya terlepas dari pengaruh kekuasaan pemerintah. Prinsip itu dimaksudkan terutama untuk menjamin adanya suatu peradilan yang benar-benar adil dan tidak memihak (fair 
tribunal and independence yudiciary). Prinsip itu juga merupakan salah satu prinsip negara hukum Indonesia seperti yang disimpulkan dalam Simposium Negara Hukum tahun 1966, juga menjadi prinsip rule of law yang dikembangkan oleh International Commission of Jurist.

Operasionalisasi konsep yuridis formal negara hukum Indonesia itu harus dimanifestasikan dalam kegiatan pembentukan hukum, penerapan dan pelayanan hukum, penegakan hukum, serta pengembangan hukum di Indonesia.

\section{Pembahasan}

Perubahan UUD 1945 yang sudah berlangsung dalam empat tahap yaitu ; tahun 1999, 2000, 2001, dan 2002, telah membawa perubahan besar dalam sistem ketatanegaraan Indonesia. Perubahan tersebut meliputi sistem pelembagaan dan hubungan tiga cabang kekuasaan negara yang utama (legislatif, eksekutif, dan yudisial), sistem pemerintahan lokal, pengaturan jaminan perlindungan hak asasi manusia yang lebih rinci.

Perubahan yang sangat mendasar itu juga mempengaruhi struktur dan mekanisme struktural organ-organ negara RI yang tidak dapat lagi dijelaskan menurut cara berpikir lama. Banyak pokok-pokok pikiran baru yang diadopsikan ke dalam kerangka UUD 1945 itu, diantaranya adalah: (a) penegasan dianutnya cita demokrasi dan nomokrasi secara sekaligus dan saling melengkapi secara komplementer; (b) pemisahan kekuasaan dan prinsip "checks and balances' (c) pemurnian sistem pemerintahan presidensial; dan (d) penguatan cita persatuan dan keragaman dalam wadah NKRI.

\section{Pemisahan Kekuasaan dan Prinsip 'Checks and Balances'}

Prinsip kedaulatan yang berasal dari rakyat tersebut selama ini hanya diwujudkan dalam MPR yang merupakan penjelmaan seluruh rakyat, pelaku sepenuhnya kedaulatan rakyat, dan yang diakui sebagai lembaga tertinggi negara dengan kekuasaan yang tidak terbatas. Dari Majelis inilah, kekuasaan rakyat itu dibagi-bagikan secara vertikal ke dalam lembaga-lembaga tinggi negara yang berada dibawahnya. Karena itu, prinsip yang dianut disebut sebagai prinsip pembagian kekuasaan (distribution of power). ${ }^{15}$ Akan tetapi, dalam UUD hasil perubahan, prinsip kedaulatan rakyat tersebut ditentukan dan dibagikan secara horizontal dengan cara memisahkannya (separation of power) menjadi kekuasaan-kekuasaan yang dinisbatkan sebagai fungsi lembaga-lembaga negara yang sederajat dan saling mengendalikan satu sama lain berdasarkan prinsip 'checks and balances'. Cabang kekuasaan legislatif tetap berada di MPR, tetapi majelis ini terdiri dari dua lembaga perwakilan yang sederajat dengan lembaga negara lainnya. Untuk melengkapi pelaksanaan tugas-tugas pengawasan, disamping lembaga legislatif dibentuk pula BPK. Cabang kekuasaan eksekutif berada ditangan Presiden dan Wakil Presiden. Untuk memberikan nasehat dan saran kepada Presiden dan Wakil Presiden, dibentuk pula Dewan Pertimbangan Presiden. Sedangkan cabang kekuasaan kehakiman dipegang oleh MA dan MK. MPR tetap merupakan rumah penjelmaan seluruh rakyat yang strukturnya dikembangkan dalam dua kamar ${ }^{16}$, yaitu DPR dan DPD . Oleh karena itu, prinsip perwakilan daerah dalam DPD harus dibedakan hakikatnya dari prinsip perwakilan rakyat dalam DPR. Maksudnya ialah agar seluruh aspirasi rakyat benar-benar dapat dijelmakan ke dalam MPR yang terdiri dari dua pintu. Kedudukan MPR yang terdiri dari dua lembaga perwakilan itu itu adalah sederajad dengan Presiden, MA dan MK. Ketiga cabang kekuasaan legislatif, eksekutif, dan yudisial itu sama-sama sederajat dan

Jimly Asshiddiqie, Struktur Ketatanegaran
Indonesia Setelah Perubahan Keempat UUD Tabun 1945.
Makalah disampaikan pada Seminar Pembangunan
Hukum Nasional VIII, Penegakan Hukum dalam
Era Pembangunan Berkelanjutan, Badan Pembinaan
Hukum Nasional, Departemen Kehakiman dan Hak
asasi Manusia RI, Denpasar, 14-18 Juli 2003.
$16 \quad$ Ibid.


saling mengontrol satu sama lain sesuai dengan prinsip 'Check and balances'. Dengan adanya prinsip 'Check and balances' ini, maka kekuasaan negara dapat diatur, dibatasi dan bahkan dikontrol dengan sebaik-baiknya, sehingga penyalahgunaan kekuasaan oleh aparat penyelenggara negara ataupun pribadipribadi yang kebetulan sedang menduduki jabatan dalam lembaga-lembaga negara yang bersangkutan dapat dicegah dan ditanggulangi dengan sebaik-baiknya. Pasal-pasal yang dapat dianggap mencerminkan perubahan tersebut antara lain adalah perubahan ketentuan pasal 5, terutama ayat (1) juncto pasal 20 ayat (1) sampai dengan ayat (5) yang secara jelas menentukan bahwa fungsi legislatif ada pada DPR, sedangkan Presiden adalah kepala eksekutif. Disamping itu, ada pula ketentuan mengenai kewenangan MPR yang tidak lagi dijadikan tempat kemana Presiden harus bertanggungjawab atau menyampaikan pertanggung-jawaban jabatannya. Selain itu, ketentuan mengenai MK yang diberi kewenangan untuk melakukan pengujian atas UU terhadap UUD seperti ditentukan dalam pasal 24 ayat (1) juga mencerminkan dianutnya asas pemisahan kekuasaan dan prinsip 'check and balances' antara cabang kekuasaan legislatif dan yudisial. Ketiga ketentuan itu memastikan tafsir berkenaan dengan terjadinya pergeseran MPR dari kedudukannya sebagai lembaga tertinggi menjadi lembaga yang sederajat dengan Presiden berdasarkan pemisahan kekuasaan dan prinsip 'check and balances'.

\section{Sistem Pemerintahan Presidensial}

Dalam sistem ini, terdapat lima prinsip penting, yaitu:

a. Presiden dan Wakil Presiden merupakan satu institusi penyelenggara kekuasaan eksekutif negara yang tertinggi di bawah UUD. Dalam menjalankan pemerintahan negara, kekuasaan dan tanggungjawab politik berada ditangan Presiden (concentration of power and responsibility upon the President);

b. Presiden dan Wakil Presiden dipilih oleh rakyat secara langsung dan karena itu secara politik tidak bertanggungjawab kepada MPR atau lembaga parlemen, melainkan bertanggungjawab langsung kepada rakyat yang memilihnya;

c. Presiden dan/atau Wakil Presiden dapat dimintakan pertanggungjawabannya secara hukum apabila Presiden dan/atau Wakil Presiden melakukan pelanggaran hukum konstitusi. Dalam hal demikian, Presiden dan/atau Wakil Presiden dapat dituntut pertanggungjawabannya oleh DPR untuk disidangkan dalam MPR, yaitu sidang gabungan antara DPR dan DPD. Namun, sebelum diberhentikan, tuntutan pemberhentian Presiden dan/atau Wakil Presiden yang didasarkan atas tuduhan pelanggaran atau kesalahan, terlebih dulu harus dibuktikan secara hukum melalui proses peradilan di MK. Jika tuduhan bersalah itu dapat dibuktikan secara hukum oleh MK, barulah atas dasar itu, MPR bersidang dan secara resmi mengambil putusan pemberhentian;

d. Para Menteri adalah pembantu Presiden, Menteri diangkat dan diberhentikan oleh Presiden dan karena bertanggungjawab kepada Presiden, bukan dan tidak bertanggungjawab kepada parlemen. Kedudukannya tidak tergantung kepada parlemen.

e. Untuk membatasi kekuasaan Presiden yang kedudukannya dalam sistem presidensial sangat kuat sesuai dengan kebutuhan untuk menjamin stabilitas pemerintahan, ditentukan pula bahwa masa jabatan Presiden lima tahunan tidak boleh dijabat oleh orang yang sama lebih dari dua masa jabatan.

\section{PerubahanStrukturdanSistemPerwakilan dan Kekuasaan Legislatif}

Setelah perubahan UUD 1945, struktur dan sistem lembaga perwakilan di Indonesia adalah sebagai berikut:

a. MPR :

- Tidak lagi berkedudukan sebagai 
lembaga tertinggi negara pelaksana sepenuhnya kedaulatan rakyat;

- Keanggotaannya terdiri dari seluruh anggota DPR dan DPD yang dipilih melalui pemilu [Pasal 2 ayat (1)];

- Kewenangannya hanya menetapkan dan mengubah UUD, melantik Presiden dan Wakil Presiden [Pasal 3 ayat (1) dan (2)], memberhentikan Presiden dan Wakil Presiden menurut ketentuan UUD [Pasal 3 ayat (3) jo. Pasal 7A dan Pasal 7B], memilih Wakil Presiden dan calon yang diajukan oleh Presiden apabila terjadi kekosongan Wakil Presiden [Pasal 8 ayat (2)], memilih Presiden dan wakil Presiden jika keduanya berhalangan tetap secara bersamaan [Pasal 8 ayat (3)].

\section{b. DPR :}

- Anggotanya dipilih melalui pemilu [Pasal 19 ayat (1)];

- Memegang kekuasaan membentuk UU [Pasal 20 ayat (1)];

- Memiliki fungsi legislasi, fungsi anggaran, dan fungsi pengawasan [Pasal 20 A ayat (1)];

- Mempunyai kewenangan: mengusulkan pemberhentian Presiden dan atau Wakil Presiden kepada MPR setelah ada putusan MK [Pasal 7 ayat (1)], memberhentikan persetujuan atas UU bersama Presiden Pasal 20 ayat (2)], pernyataan perang, membuat perdamaian dan perjanjian dengan negara lain yang dilakukan Presiden (Pasal 11), persetujuan calon Hakim Agung atas usulan Komisi Yudisial, memberikan pertimbangan kepada Presiden atas pengangkatan duta [Pasal 13 ayat (2)], menerima penempatan duta negara lain [Pasal 13 ayat (3)], dan pemberian amnesti dan abolisi Pasal 14 ayat (2)], memilih calon anggota Badan Pengawas keuangan (BPK) [Pasal $23 \mathrm{~F}$ ayat (1)], dan mengusulkan 3 orang calon Hakim Konstitusi kepada Presiden [Pasal 24 C ayat (3]. c. DPD :

- Anggotanya mewakili setiap propinsi yang dipilih melalui pemilu Pasal 22 $C$ ayat (1)] dan semua anggotanya otomatis adalah anggota MPR [Pasal 2 ayat (1)], jumlah anggota setiap propinsi sama dan secara keseluruhan tidak boleh lebih dari sepertiga jumlah anggota DPR [Pasal 22 ayat (2)];

- Mempunyai kewenangan untuk mengusulkan kepada DPR [Pasal 22 D ayat (2) RUU yang berkaitan dengan otonomi daerah, hubungan pusat dan daerah, pembentukan dan pemekaran serta penggabungan daerah, pengelolaan sumber daya alam dan sumber daya ekonomi lainnya, serta yang berkaitan dengan perimbangan keuangan pusat dan daerah, memberikan pertimbangan kepada DPR atas RUU APBN dan RUU yang berkaitan dengan pajak, pendidikan dan agama [Pasal $22 \mathrm{D}$ ayat (2)], serta pemilihan anggota BPK Pasal $23 \mathrm{~F}$ ayat (1)], dan dapat melakukan pengawasan atas pelaksanaan undangundang mengenai otonomi daerah, pembentukan, pemekaran dan penggabungan daerah, hubungan pusat dan daerah, pengelolaan sumber daya alam dan sumber daya ekonomin lainnya, pelaksanaan APBN, pajak, pendidikan, dan agama [Pasal $22 \mathrm{D}$ ayat (3)].

Dengan demikian, dalam sistem perwakilan dan kekuasaan legislatif telah terjadi perubahan yang sangat signifikan sebagai berikut:

a. Tidak ada lagi supremasi MPR, melainkan adanya kecenderungan dianutnya teori trias politika dengan prinsip checks and balances;

b. Pergeseran dari sistem unikameral ke sistem semi-bikameral dengan adanya DPD meskipun dengan peran yang sangat terbatas, dan hilangnya sistem perwakilan fungsional dengan hapusnya utusan golongan di MPR;

c. Pergerseran kekuasaan membentuk UU dari Presiden ke DPR. 


\section{Perubahan Kekuasan Eksekutif}

Sesuai dengan prinsip perubahan UUD 1945 untuk mempertegas sistem presidensial dan dianutnya pemisahan cabang-cabang kekuasan negara yang utama dengan prinsip checks and balances, maka dengan perubahan UUD 1945 berimplikasi pula perubahan di bidang kekuasaan eksekutif (Presiden) sebagai berikut:

a. Presiden sebagai pemegang kekuasaan eksekutif [Pasal 4 ayat (1)] tidak lagi memegang kekuasaan membentuk UU yang telah bergeser ke tangan DPR [Pasal 20 ayat (1)], melainkan hanya berhak mengajukan RUU ke DPR [Pasal 5 ayat (19)], memberikan persetujuan bersama dengan DPR dan mengesahkan RUU menjadi UU [Pasal 20 ayat (2) dan (4)];

b. Presiden dan wakil Presien tidak lagi dipilih oleh MPR, melainkan dipilih oleh rakyat secara langsung secara berpasangan dari calon yang diajukan oleh partai politik atau gabungan partai politik (Pasal 6A);

c. Masa jabatan Presiden selama 5 (lima) tahun secara tegas dibatasi untuk dua periode (Pasal 7);

d. Ditentukan syarat-syarat yang lebih rinci untuk menjadi Presiden dan Wakil Presiden (Pasal 6);

e. Ditentukannya mekanisme impeachment terhadap Presiden dan Wakil Presiden yang melibatkan DPR, MK, dan MPR (Pasal 7A dan 7B);

f. Penegasan bahwa Presiden tidak dapat membubarkan DPR (Pasal 7C);

g. Pelaksanaan hak-hak prerogatif Presiden sebagai kepala negara harus dengan persetujuan atau pertimbangan DPR;

h. Pengangkatan pejabat-pejabat publik, seperti anggota BPK (Pasal 23F), Hakim Agung [Pasal 24A ayat (3)], anggota Komisi Yudisial [Pasal 24B ayat (3) harus dengan persetujuan DPR;

i. Presiden berwenang membentuk dewan pertimbangan (Pasal 16) sebagai pengganti DPA yang dihapuskan; j. Dalam pembentukan, pengubahan dan pembubaran kementerian harus diatur dengan UU [Pasal 17 ayat (4)], tidak bebas seperti sebelumnya.

\section{Sistem Kekuasaan Kehakiman(Kekuasaan Yudisial)}

Di bidang kekuasaan kehakiman (kekuasaan yudisial) perubahan UUD 1945 telah menentukan hal-hal sebagai berikut:

a. Penegasan tentang independensi kekuasaan kehakiman ([Pasal 24 ayat (1) UUD 1945], sedangkan sebelumnya hanya dalam Penjelasan (ini sebagai konsekuensi dihapusnya bagian Penjelasan UUD 1945);

b. Kekuasan kehakiman tidak lagi hanya monopoli MA dengan badan-badan peradilan yang berada dibawahnya, melainkan juga oleh MK [Pasal 24 ayat (2) UUD 1945];

c. Adanya Komisi Yudisial yang bersifat mandiri yang berwenang mengusulkan pengangkatan Hakim Agung dan mempunyai wewenang lain dalam rangka menjaga dan menegakkan kehormatan, keluhuran martabat, serta perilaku hakim (Pasal 24B);

d. Kehadiran MK dengan 9 (sembilan) hakim konstitusi (tiga orang usulan DPR, tiga orang usulan MA, dan tiga orang usulan Presiden) yang mempunyai empat kewenangan dan satu kewajiban (Pasal 24C UUD 1945):

e. Menguji UU terhadap UUD 1945;

f. Memutus sengketa kewenangan konstitusional lembaga negara;

g. Memutus pembubaran partai politik;

h. Memutus perselisihan hasil pemilu;

i. Wajib memutus pendapat DPR tentang impeachment terhadap Presiden. Semua peradilan untuk empat kewenangan tersebut diatas merupakan peradilan tingkat pertama dan terakhir yang putusannya bersifat final. Sedangkan putusan untuk kewajiban MK masih akan ditentukan oleh 
mekanisme putusan politik di DPR dan MPR [vide pasal 7B ayat (5), (6), dan (7)];

j. Penegasan tentang judicial review, yaitu bahwa pengujian peraturan perundangundangan di bawah UU terhadap UU oleh MA. Sedangkan untuk pengujian konstitusionalitas UU oleh MK.

Khusus untuk MK yang kemudian diatur dalam UU No. 24 Tahun 2003 tentang MK (LN RI Th. 2003 No. 98, TLN RI No. 4316) dalam usia genap satu tahun (resmi berdiri 13 Agustus 2003) telah melaksanakan dua kewenangannya, yaitu melakukan pengujian konstitusionalitas sekitar $24 \mathrm{UU}$ dan memutus perselisihan hasil pemilu (44 permohonan Pemilu Legislatif dan satu permohonan Pemilu Presiden dan Wakil Presiden).

\section{Penutup}

Dari hasil penelitian dapat disimpulkan bahwa, ada perubahan yang mendasar pada kewenangan kelembagaan negara setelah perubahan UUD 1945 terkait dengan pola pembagian kekuasaan pada tiga cabang kekuasaan (legislatif, eksekutif, dan yudisial). Pada lembaga legislatif ada pembagian tugas yang jelas terutama dalam pembuatan UU, karena UUD 1945 telah menentukan bahwa lembaga pembentuk UU adalah DPR . Di sisi lain, lembaga yudisial telah memperkuat fungsi dan peranannya di bidang peradilan dengan membentuk institusi baru yaitu MK. Lembaga ini berwenang melakukan uji materi (judicial review) UU atas UUD, yang sebelumnya menjadi tugas dari MA.

Dengan demikian dapat dapat disarankan beberapa hal sebagai berikut: 1) Perlu adanya konsistensi pembagian tugas di masing-masing lembaga-lembaga negara sesuai dengan ketentuan dalam UUD 1945; 2) Perlu ditingkatkan saling koordinasi dan mengawasi antar lembaga baik dalam garis vertikal maupun horizontal; 3) Membangun paradigma baru untuk menegakkan konsep negara hukum sebagai perwujudan cita-cita Bangsa Indonesia.

\section{Daftar Bacaan}

Azhary, Muhammad Tahir. 2004. Negara Hukum (Suatu Studi tentang Prinsipprinsipnya Dilibat dari Segi Hukum Islam, Implementasinya pada Periode Negara Madinah dan Masa Kini). Jakarta: Prenada Media.

Churchill, Greory. 1991. Petunjuk Penelusuran Literatur Hukum Indonesia. Jakarta: Fakultas Hukum UI.

Fadjar, A. Mukthie. 2004. Negara Hukum. Malang: Bayumedia.

Locke, John. 2002. Kuasa Itu Milik Rakyat (Esai Mengenai Asal Mula Sesunggubnya, Ruang Lingkup, dan Maksud Tujuan Pemerintaban Sipil), Terjemahan. Yogyakarta: Kanisius.

Mahfud, Moh. 1999. Amandemen Konstitusi Menuju Reformasi Tatanegara, Yogyakarta: UII Press.

Manan, Bagir, 2000. Pembaruan UUD 1945, Jurnal Magister Hukum, Vol. 2 No.1.

Marzuki, Peter Mahmud. 2005. Penelitian Hukum. Jakarta: Prenada Media.

Nasution, Adanan Buyung, 1995. Aspirasi Pemerintahan Konstitusional di Indonesia (Terjemahan Sylvia Tiwon). Jakarta: Grafiti Press.

Sekretariat Jenderal MPR RI. 2006. Panduan Pemasyarakatan Undang-Undang Dasar Negara Republik Indonesia Tabun 1945 (Sesuai dengan Urutan Bab, Pasal, dan Ayat). Jakarta: Sekjen MPR RI.

, 2006. Bahan Tayangan Materi Sosialisasi Undang-Undang Dasar Negara Republik Indonesia Tahun 1945. Jakarta: Sekjen MPR RI.

Sinaga, Budiman, 2005. Hukum Konstitusi, Yogyakarta: Kurnia Kalam Semesta.

Syahuri, Taufiqurrohman. 2004. Hukum Konstitusi Proses dan Prosedur Perubaban UUD di Indonesia 1945-2002, Serta Perbandingannya dengan Konstitusi Negara Lain di Dunia). Bogor: Ghalia Indonesia. 